\title{
Unraveling the Complexity of Coffee Leaf Rust Behavior and Development in Different Coffea arabica Agroecosystems
}

\author{
Isabelle Merle, $, 1,2, \dagger$ Jimmy Pico, ${ }^{3,4}$ Eduardo Granados, ${ }^{5}$ Audrey Boudrot, ${ }^{6}$ Philippe Tixier,7 Elías de Melo Virginio Filho, ${ }^{4}$ \\ Christian Cilas, ${ }^{1,8}$ and Jacques Avelino ${ }^{1,2,4,9}$ \\ ${ }^{1}$ Bioagresseurs, Université de Montpellier, CIRAD, Montpellier, France \\ ${ }^{2}$ CIRAD, UPR Bioagresseurs, 30501 Turrialba, Costa Rica \\ ${ }^{3}$ INIAP, Estación experimental Joya de los Sachas 220350, Orellana, Ecuador \\ ${ }^{4}$ CATIE, 7170, Cartago, Turrialba, 30501, Costa Rica \\ ${ }^{5}$ Universidad de Costa Rica, sede del Atlántico, Turrialba, Costa Rica \\ ${ }^{6}$ Agrocampus Ouest, 65, rue de Saint Brieuc 35000 Rennes, France \\ ${ }^{7}$ CIRAD, UPR GECO, F-34398 Montpellier, France, and GECO, Université de Montpellier, CIRAD, Montpellier, France \\ ${ }^{8}$ CIRAD, UPR Bioagresseurs, F-34398 Montpellier, France \\ ${ }^{9}$ IICA AP. 55, 2200 Coronado, San Jose, Costa Rica \\ Accepted for publication 4 September 2019.
}

\begin{abstract}
Crop health management systems can be designed according to practices that help to reduce crop losses by restricting pathogen development and promoting host plant growth. A good understanding of pathogen and host dynamics, which are interdependent, is therefore needed. In this article, we used a holistic approach to explain the behavior of coffee leaf rust (CLR), a major coffee disease. We monitored coffee plant and CLR dynamics simultaneously in plots under different disease management and agroforestry systems. Diseased leaves were also collected to characterize inoculum

This overview integrates processes such as disease dilution by host leaf renewal, direct and indirect effects of fruit load on CLR development, antagonistic effects of shading depending on rust life stages, the tonic effect of copper-based fungicides on leaf retention, and effects on rust life stages depending on fungicide types. From our results, we also deduced that the inoculum stock could be calculated in unsprayed plots from the rust area with uredospores, with uredospores at $58 \times 10^{3} \mathrm{~cm}^{-2}$, on average.
\end{abstract} stock and rust life stages (latent rust area, area with uredospores, necrosis due to rust) through picture analysis. We used structural equation modeling to obtain an overview of CLR pathosystem functioning on a plant scale.
Keywords: agroforestry, coffee phenology, ecology and epidemiology, Hemileia vastatrix, rust life stages, structural equation modeling
Plant epidemics are driven by plant growth and pathogen development in interaction with their environment and cropping practices, as illustrated in the disease tetrahedron (Zadoks and Schein 1979). Optimizing disease control in crops requires a good understanding of interactions and their temporal dynamics. Overall balances may indicate no general effect of a specific factor because of antagonistic effects via different pathways, whose identification could nevertheless help to improve disease control (Calonnec et al. 2013). The way a disease is measured can also lead to similar issues. In epidemiological studies of leaf diseases, researchers often use incidence or severity (i.e., relative number of leaves or leaf area affected by disease). However, these indicators can be difficult to interpret, because they can differ due to variations of plant foliage density or pathogen growth (Ferrandino 2008; Waller 1982). Disease development can be described more precisely by characterizing the evolution of symptoms and signs, independently of variations in host

†Corresponding author: I. Merle; isabelle.merle@protonmail.com

Funding: This work was developed as part of the "Programa Centroamericano de Gestión Integral de la Roya del Café" (PROCAGICA) funded by the European Union (DCI-ALA/2015/365-17). We thank the Ernesto Illy Foundation and Centre de Coopération Internationale en Recherche Agronomique pour le Développement (CIRAD) through the SAFSE project (search for trade-offs between production and ecosystem services provided by agroforestry systems) for their financial support.

The author(s) declare no conflict of interest.

(C) 2020 The American Phytopathological Society foliage density. This approach is also useful for identifying disease drivers depending on pathogen development stages.

Understanding the relationships between the host plant, the pathogen, and management practices is even more important for tropical and perennial crops because, unlike temperate climates, tropical climates do not benefit from strong weather variations that contribute to natural disease regulation. In the case of perennial crops, certain effective practices such as crop rotations used with annual crops to control diseases cannot be implemented. However, other practices such as pruning can be applied as part of a control strategy. Agroforestry, which is common in perennial tropical crops such as coffee, is an additional option for influencing pathways that can help to regulate pests and diseases (Avelino et al. 2011; Poeydebat et al. 2018).

In Central America, despite the reduction in shade-grown coffee areas observed over the last two decades (Jha et al. 2014; Perfecto et al. 1996), coffee growing in agroforestry systems is still common. Shade trees are also often recommended for coping with the expected temperature increases in the near future (Lasco et al. 2014). However, the effects of shade trees on the development of coffee diseases are not yet fully understood. In particular, contradictory results have been obtained about how shade influences coffee leaf rust (CLR), a polycyclic disease caused by the fungus Hemileia vastatrix (Berk. \& Broome) (Avelino et al. 2006; Roberts and Paul 2006; Salgado et al. 2007; Soto-Pinto et al. 2002; Staver et al. 2001). Shade effects on CLR result from direct effects on the pathogen, indirect effects via coffee phenology and natural enemies, along with delayed effects via disease impacts on coffee phenology. For instance, shade trees indirectly influence CLR incidence via coffee leaf growth, leaf lifespan, and fruit load, 
and by increasing the abundance of the mycoparasite fungus Lecanicillium lecanii (Zimm.) Zare \& W. Gams (Avelino et al. 2006; Bock 1962; Campanha et al. 2004; Charbonnier et al. 2013; Costa et al. 2006; Cournede et al. 2007; De Carvalho et al. 2001; Kushalappa 1981; Kushalappa and Ludwig 1982; Kushalappa et al. 1983; López-Bravo et al. 2012; Vandermeer et al. 2009).

Similarly, fungicides can affect diseases through direct effects on the pathogen and indirect effects via natural enemies and the host plant. Fungicide direct effects on CLR depend on the properties of the molecules, which can be protectant, curative, or eradicant. Fungicides also influence CLR by reducing the abundance of its mycoparasite, the fungus, L. lecanii (Castellanos et al. 2012; Jackson et al. 2012; Vandermeer et al. 2009). Moreover, fungicides can affect coffee phenology, and therefore CLR, through a "tonic" effect on leaf retention (Bock 1962; Brinate et al. 2015; Cannell 1985; da Cunha et al. 2004; Mulinge and Griffiths 1974; Van der Vossen and Browning 1978).

Several reviews have reported many relationships existing between the coffee plant and $H$. vastatrix, or the environment and this pathogen, with some including management practices to control the disease (Avelino et al. 2004, 2018; Hindorf and Omondi 2011; McCook and Vandermeer 2015; Talhinhas et al. 2017; Zambolim 2016). However, these relationships are often balances of effects and do not provide a fine understanding of the functioning of the pathosystem. In our study, we set out to integrate in a holistic analysis the relationships that exist between cropping practices, coffee phenology, and the different CLR development stages, highlighting pathways and dynamics within that system. To that end, we used a structural equation modeling (SEM) approach, which had proved to be useful in a previous study to identify the main factors explaining coffee production losses caused by pests and diseases (Cerda et al. 2017).

\section{MATERIALS AND METHODS}

Study site. The experiment was carried out from August 2013 to December 2014 in the long-term coffee-based agroforestry systems trial, covering an area of 9.2 ha, located at Centro Agronómico Tropical de Investigación y Enseñanza (CATIE) in Turrialba, Costa Rica (9 $9^{\circ} 53^{\prime} 44^{\prime \prime}$ latitude north, 8340'7" longitude west). This trial was set up at an altitude of $600 \mathrm{~m}$ above sea level, under a Caribbean influence (i.e., with no well-marked dry season). The 2004 to 2014 annual average rainfall, relative humidity, and temperature were $2,779 \mathrm{~mm}, 90.8 \%$, and $22.2^{\circ} \mathrm{C}$, respectively (CATIE campus weather station). In 2013, rainfall only reached $1,945 \mathrm{~mm}$. One dry season was identified, with daily rainfall below $10 \mathrm{~mm}$, between 21 January 2014 and 8 April 2014 (Boudrot et al. 2016). The small trial area prevented macroclimate differences between plots.
Experimental design. The CATIE agroforestry systems trial located in Turrialba was set up in 2000. Arabica coffee plants of the Caturra dwarf variety, susceptible to most rust races, were planted at a 2-by-1-m planting density (5,000 coffee plants ha $\left.{ }^{-1}\right)$. Among the 20 treatments replicated randomly over three blocks available in this trial (Haggar et al. 2011), 4 of them, where organic and moderate chemical controls were applied, were selected for our study. Two additional treatments that were conventionally managed but with no chemical or organic control throughout the year were established using available coffee areas. From these 6 initial treatments, we built and studied 12 (Table 1), resulting from the combination of shade (three levels, see following section) and fungicide nature applied in the last 40 days (four levels, see following section and section on description of variables).

The 18 study plots (six treatments from the agroforestry system trial $\times$ three replicates) measured from 300 to $450 \mathrm{~m}^{2}$ and differed in terms of shade cover and management strategy (Table 1). Three shade cover levels were studied, including full sun; Erythrina poeppigiana, the Poró tree, alone (278 trees ha-1); and $E$. poeppigiana (164 trees $\mathrm{ha}^{-1}$ ) combined with Chloroleucon eurycyclum, the Cashá tree $\left(78\right.$ trees $\left.\mathrm{ha}^{-1}\right)$. E. poeppigiana is a legume tree pruned twice a year: drastic pruning to a height of $2 \mathrm{~m}$ in January and regulation pruning to a height of $4.5 \mathrm{~m}$ in June. C. eurycyclum is a free-growth legume tree, reaching 22 to $24 \mathrm{~m}$ high in the trial. In the E. poeppigiana plots, shade cover ranged from 15 to $36 \%$, depending on the period and pruning activities. In the E. poeppigiana + C. eurycyclum plots, shade cover ranged from 30 to $60 \%$. In plots under conventional management, chemical fertilizer applications were carried out using 18:5:15 N-P-K at $500 \mathrm{~kg} \mathrm{ha}^{-1}$ and 33.5:0:0 N-P-K (urea) at $180 \mathrm{~kg} \mathrm{ha}^{-1}$. Disease control over the study period was achieved with three applications of a commercial copper-based fungicide $(50 \% \mathrm{Cu})$ at $1 \mathrm{~kg} \mathrm{ha}^{-1}$ in March and April 2013 and March 2014, combined with three applications of a systemic fungicide (cyproconazole 10\% WG) at 0.4 liter ha ${ }^{-1}$ in June 2013 and January and June 2014. In organically managed plots, nutrition was based on applying chicken manure (10 $\mathrm{t} \mathrm{ha}^{-1}$ ) and K-MAG, a potassium, magnesium, and sulfur fertilizer $\left(100 \mathrm{~kg} \mathrm{ha}^{-1}\right)$. In these plots, disease control was achieved by applying Bordeaux mixture (20\% copper and $10 \%$ calcium) at $1.5 \mathrm{~kg} \mathrm{ha}^{-1}$ on seven dates in February, April, and June 2013 and January, April, March, and June 2014.

Field monitoring of coffee phenology and rust development. Six coffee plants were selected in each plot in August 2013 and monitored every 21 days until December 2013. Due to severe damage caused by the 2013 epidemic, particularly in untreated plots, all of the plants were discarded and six new plants were selected in January 2014 for the 2014 measurements. On each coffee plant, three branches in the upper, middle, and lower strata of the plant were

TABLE 1. Studied combinations of three shade levels and four levels of fungicide applied during the last 40 days and their associated fertilization management

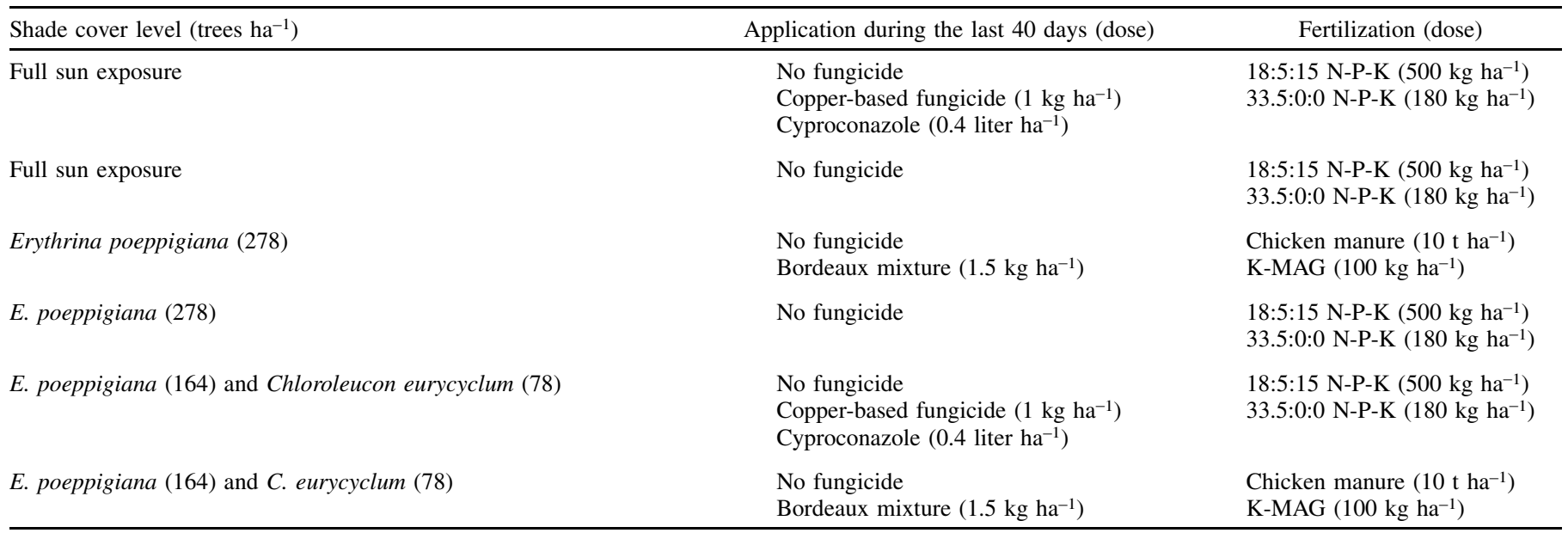


labeled (one per coffee plant stratum). Leaf growth and defoliation (leaf area), and rust development on those branches, were assessed using the methodology established by Kushalappa (1981). That method enabled nondestructive and leaf-by-leaf monitoring. In each node of the labeled branches, the presence or absence of leaves was registered. Their area was assessed with an accuracy of $10 \mathrm{~cm}^{2}$, using patterns of different sizes. The total rust lesion area was assessed with a diagrammatical scale representing eight damaged areas ranging from 0.1 to $10 \mathrm{~cm}^{2}$. The annual mean coffee plant fruit load was estimated per plot by counting and averaging the number of fruiting nodes on the six selected coffee plants. Because this was a nondestructive method, field monitoring made it possible to observe the temporal dynamics of coffee phenology and rust area; however, it was not possible to characterize in detail different rust development stages such as latency and sporulation.

Laboratory measurements of rust areas, presence of rust area parasitized with $L$. lecanii, and presence of necrosis due to rust and rust inoculum stock. Field monitoring was combined with laboratory measurements to assess the area with uredospores, recognizable by their intense orange color and powdery aspect; the rust latent area, exhibiting chlorosis with no uredospores; the area of necrosis due to rust, a brown surface generally located in the center of old rust lesions; and the area of rust lesions parasitized with the fungus L. lecanii (or similar fungi such as Simplicillium spp.), visually identifiable on some rust lesions by its white color and powdery aspect. In addition, the rust inoculum stock was assessed.

Every 3 weeks, all of the diseased leaves from six randomly chosen branches (two branches $\times$ three strata) and six coffee plants (one branch per coffee plant), different from those chosen for field monitoring, were collected in each plot. Photographs of leaves were taken and identified by the coffee plant and stratum from which they originated. A graduated ruler was included in the photograph to show its scale. The abovementioned areas were measured using Image Tool version 3.0 software, developed by Wilcox et al. (2002) and Texas University. The amount of rust inoculum on the collected leaves was quantified by harvesting the uredospores, rasping the areas showing signs, and placing them in Eppendorf tubes containing $1 \mathrm{ml}$ of a $2.5 \%$ Tween aqueous solution to prevent uredospore aggregation. Each sample was homogenized for $5 \mathrm{~min}$ at $30^{\circ} \mathrm{C}$ in an ultrasonifier Steri-Cleaner (Strudi Industrial Co). Rust uredospores were counted with a Neubauer counting chamber, containing $7 \mu l$ of the suspension, with the $\times 10$ power objective lens. Because this was a destructive method, the leaf collection experiment did not allow us to appreciate temporal dynamics; however, we were able to describe several rust life cycle stages separately, along with one of its natural enemy, L. lecanii.

Description of variables and reference modalities in statistical analysis. In both experiments, based on nondestructive field monitoring and laboratory measurements, the two factors Shade and Fungicides were used to describe the agronomical management of both the coffee plant and CLR systems (Table 2). The Shade factor described the type of agroforestry system. Its effect was compared with the full sun exposure treatment, considered as the reference modality. Shade is responsible for microclimate variations between plots, which are all under the same macroclimate. Shade affects coffee phenology and rust development via this main pathway. The Fungicides factor described chemical rust control (i.e., the fungicide type [copper-based or triazole] combined with a dosage, applied in the last 40 days, to consider fungicide effective life) (Santos et al. 2002). For this factor, the reference modality was the absence of fungicide applied in the last 40 days.

In the nondestructive field monitoring experiment, all of the quantitative variables except the mean coffee plant fruit load were expressed per branch and averaged per coffee stratum. Seven variables were studied: five variables to characterize coffee plant phenology and two variables to characterize CLR development (Table 2). Coffee plant phenology was characterized by the coffee branch stratum (Leaf Stratum: Top, Middle, and Bottom of the coffee tree), mean number of fruiting nodes per coffee plant (Fruit Load), total leaf area per branch at the previous evaluation (i.e., 21 days before) (Leaf Area $_{\mathrm{d}-21}$ ), leaf growth (growth in area from existing leaves and new leaves) since the previous evaluation (Leaf Growth), and lost leaf area due to leaf fall since the previous evaluation (Leaf Fall). We chose the Top stratum as the reference modality for the Leaf Stratum variable because that stratum is the most exposed to sunlight like the reference modality of the Shade factor. CLR development was characterized by the rust area per branch at the previous evaluation (Rust Area $_{\mathrm{d}-21}$ ) and current rust area per branch (Current Rust Area).

In the leaf collection experiment, all of the quantitative variables except the mean coffee plant fruit load were expressed per branch. Seven variables were studied: two variables to characterize coffee plant phenology, four variables to characterize CLR development, and one for the natural enemy L. lecanii (Table 2). The coffee branch stratum (Leaf Stratum) and the mean number of fruiting nodes per

TABLE 2. Description of the coffee plant, the coffee leaf rust, and the cropping practice variables used in the field monitoring and laboratory measurements

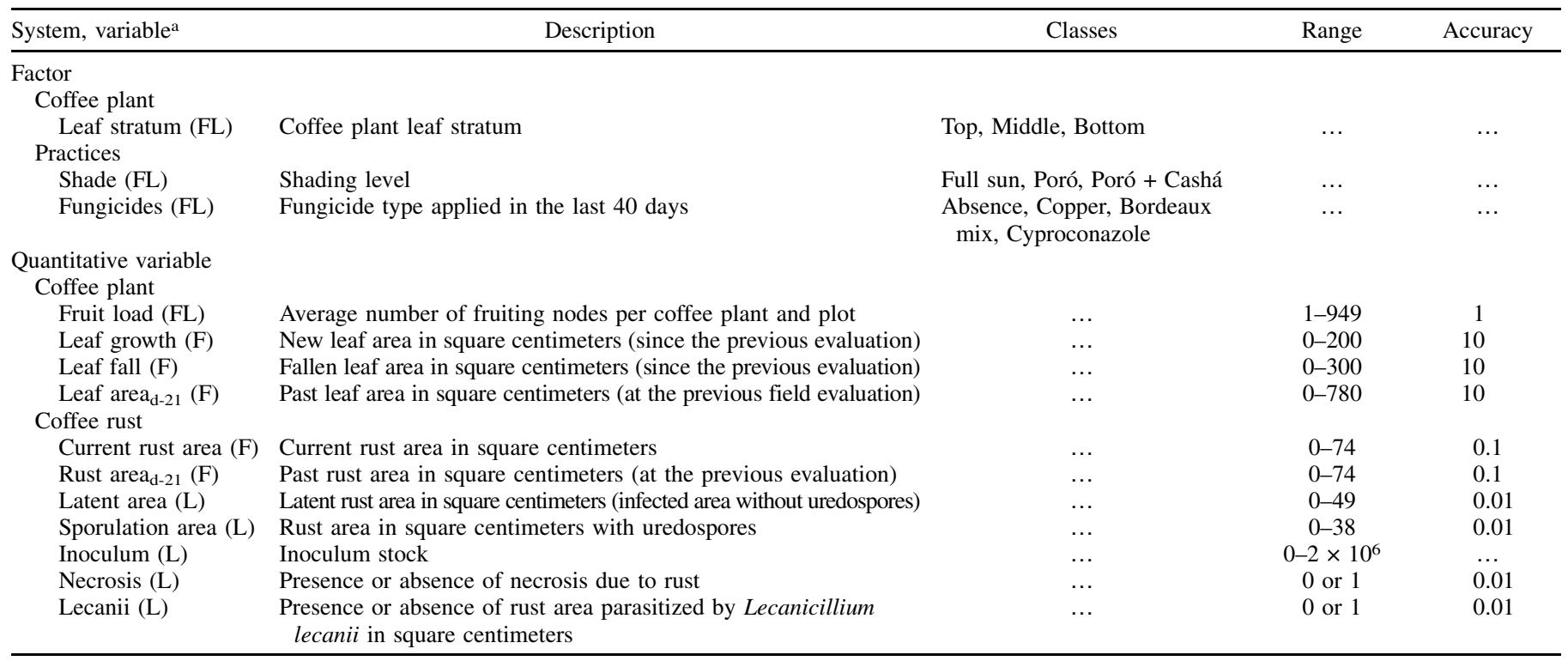

${ }^{\mathrm{a}} \mathrm{F}=$ variables from field experiment and $\mathrm{L}=$ variables from laboratory measurements. 
coffee plant (Fruit Load) characterized coffee plant phenology. CLR on the collected leaves was described by the latent rust area (Latent Area), the area with uredospores (Sporulation Area), inoculum stock (Inoculum), and presence of necrosis due to rust (Necrosis). The presence of rust area parasitized by L. lecanii (Lecanii) was also considered.

All of the variables were rounded off considering measurement accuracy, and the Leaf Area ${ }_{\mathrm{d}-21}$, Leaf Growth, Leaf Fall, Fruit Load, and Inoculum variables were rescaled by dividing by a constant in order to respond to rescaling needs for SEM analysis.

Statistical analysis. We formulated two global path models (Table 3), one for each experiment, which we tested using SEM. This method can be used to "examine simultaneous influences and responses", stringing together a series of submodels "to model multivariate relationships" (Grace 2006). In other words, SEM is a pathway analysis that focuses on the chain of causality between variables, in order to take into account cascading effects. For the field monitoring experiment, the global model contained three hypothetical submodels describing coffee tree phenology and rust temporal dynamics as functions of past coffee phenology, past rust area, and variables describing management practices (Table 2). For the leaf collection experiment, the submodels were designed to explain the relationships between several rust life cycle stages, one of its natural enemy, coffee fruit load, agroforestry practices, and disease control management, without temporal dynamics (Table 2). We used the piecewiseSEM R-package version 1.2.1. (Lefcheck 2016) to build and to fit these two sets of generalized linear mixed models (GLMMs) (Bolker et al. 2009) constituting our structural equation models (SEM).

The two variables describing presence or absence of necrosis due to rust and L. lecanii were fitted to a binomial distribution. Other response variables were semicontinuous (nonnegative data) discretized variables that we fitted to a Poisson distribution. In all of the GLMMs, we included the following variables as crossed random intercept effects (Zuur et al. 2009) to consider the spatial and temporal nonindependence of sampling: the block, the entity monitored (concatenation of the block, Shade $x$ management, and Leaf Stratum), and the day of monitoring or leaf collection. In the SEM approach, the Shipley test was used to analyze the missing paths (Shipley 2009). This test is a confirmatory path analysis that evaluates the hypothetical causal relationships not considered in the SEM but present in the diagram acyclic graphs (feedback relationships excluded). The global path model is valid if the $\chi^{2}$ test of adequacy between data and the model provides a $P$ value $>0.05$. All of the statistical analyses were performed with R 3.5.1 (R Development Core Team 2018) and with an $\alpha$ level of 0.05 .

\section{RESULTS}

Field monitoring of coffee phenology and rust development. For the field monitoring experiment, the validated SEM (Fig. 1), which fitted the data best (Fisher's test, $P=0.969$ ), brought out 15 significant relationships between variables, including 14 of the 18 tested relationships from the formulated SEM and 1 provided by the Shipley test for missing paths.

In this SEM (Fig. 1), the random factor Block was discarded because its effect was not significant in any submodel. Branch leaf area growth was mainly explained by the location of the branch in the bottom and middle coffee plant strata $(P<0.0001$ for both), a higher past leaf area per branch (Leaf Area L $\left._{\mathrm{d}-21}\right)(P<0.0001)$, and a lower fruit load $(P<0.0001)$. The negative effect of the past rust area (Rust Area $\left._{\mathrm{d}-21}\right)$ on branch leaf area growth was less $(P=$ 0.0082). Branch leaf fall was the result of major negative effects (reduced leaf fall) of all copper-based fungicides, with a greater effect of Bordeaux mixture, while cyproconazole had no effect $(P=$ $0.0706)$. The past leaf area $(P<0.0001)$ and past rust area $(P<$ $0.0001)$ had major positive effects on branch leaf fall, while the positive effect of fruit load $(P<0.0001)$ was less. The current rust area was mainly negatively affected by fungicide applications $(P<$ 0.0001 for all fungicides) and increased by the past rust area $(P<$ $0.0001)$ and past leaf area $(P<0.0001)$. On a second level, variables such as the fruit load of the coffee plant $(P<0.0001)$ and bottom and middle coffee leaf strata $(P<0.0001$ and $P=0.0013$, respectively) were positively related to the current rust area. Compared with full sun exposure, shade provided by the combination of Poró and Cashá $(P=0.0059)$ affected the current rust area positively, while the Poróbased agroforestry system did not show any effect $(P=0.3708)$. Branch leaf fall $(P<0.0001)$ had a minor negative effect on the increase in rust area.

Laboratory measurements of rust areas, presence of rust area parasitized with $L$. lecanii, presence of necrosis due to rust, and rust inoculum stock. For the laboratory measurements, the validated SEM, which fitted the data best (Fisher's test, $P=0.351$ ), brought out 15 significant relationships between variables, including 12 of the 24 tested relationships from the formulated SEM and 3 provided by the Shipley test for missing paths.

In the SEM obtained (Table 4), bottom and middle strata had positive effects on the latent rust area $(P<0.0001$ for both strata),

TABLE 3. Description of the structural equation modeling (SEM) submodels from the field monitoring experiment and from the leaf collection experiment

\begin{tabular}{|c|c|}
\hline SEM, response variables & Explanatory variables ${ }^{\mathrm{a}}$ \\
\hline \multicolumn{2}{|l|}{ Field monitoring } \\
\hline Leaf growth & Shade $^{1}+$ leaf stratum + fruit $l o a d^{2}+$ leaf rea $_{\mathrm{d}-21^{3}}$ \\
\hline Leaf fall & 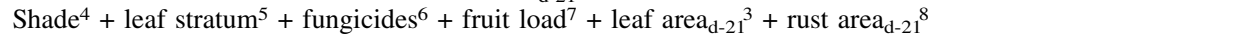 \\
\hline \multicolumn{2}{|r|}{ 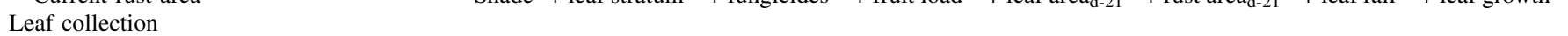 } \\
\hline Latent area & Shade $^{9}+$ leaf stratum ${ }^{10}+$ fungicides $^{11}+$ fruit load ${ }^{12}$ \\
\hline Sporulation area & Shade $^{16}+$ leaf stratum + fungicides $^{17}+$ latent area \\
\hline Inoculum & Shade $^{18}+$ leaf stratum + fungicides + latent area + sporulation area \\
\hline
\end{tabular}

a Superscript numbers indicate references supporting some of the relationships present in the submodels, as follows. $1=($ Campanha et al. 2004; Charbonnier et al. 2013; Jaramillo-Botero et al. 2010; López-Bravo et al. 2012), 2 = (Bote and Jan 2016; Cannell 1985; Vaast et al. 2005), $3=($ Cournede et al. 2007), $4=$ (Campanha et al. 2004; López-Bravo et al. 2012; Staver et al. 2001), $5=$ (Avelino et al. 1991), 6 = (Bock 1962; Brinate et al. 2015; Cannell 1985; da Cunha et al. 2004; Mulinge and Griffiths 1974; Van der Vossen and Browning 1978), 7 = (Bote and Jan 2016; Vaast et al. 2005), $8=$ (Brown et al. 1995; Kushalappa and Lagesse 1981), 9 = (Allinne et al. 2016; Avelino et al. 2006; Roberts and Paul 2006; Salgado et al. 2007; Soto-Pinto et al. 2002; Staver et al. 2001), 10 = (Avelino et al. 1991; Bock 1962; Martins et al. 2015; Villegas García and Baeza-Aragón 1990), 11 = (Capucho et al. 2013; Chalfoun and Carvalho 1999; da Cunha et al. 2004; De Carvalho et al. 2012; de Souza et al. 2011; Mulinge and Griffiths 1974; Rayner 1962; Santos et al. 2002; Waller 1982), $12=($ Avelino et al. 2006; Costa et al. 2006; De Carvalho et al. 2001; López-Bravo et al. 2012), 13 = (Avelino et al. 2006; Bock 1962; Kushalappa 1981; Kushalappa et al. 1983), 14 = (Kushalappa 1981), $15=($ Bock 1962; Kushalappa 1981), $16=($ Eskes 1982), $17=($ Coutinho et al. 1995; Rozo-Peña and Cristancho-Ardila 2010$), 18=($ Toniutti et al. 2017), $19=($ Rozo-Peña and Cristancho-Ardila 2010), $20=($ Vandermeer et al. 2009), $21=($ Castellanos et al. 2012), and 22 = (Martins et al. 2015). 
with a greater effect of the bottom stratum. The only effect of fruit load on the inoculum stock was positive $(P=0.0001)$. In terms of management strategy, fungicide applications negatively affected rust development (i.e., the latent rust area) $(P<0.001$ for all fungicides), the area with uredospores $(P=0.0033$ for Bordeaux mixture and $P<0.0001$ for the commercial copper-based fungicide and cyproconazole applications), and the rust inoculum stock $(P<$ 0.001 for all fungicides), while the fungus $L$. lecanii was not affected. For all the rust development stages, the commercial copper-based fungicide application was more efficient than the cyproconazole application, and the application of Bordeaux mixture was the least efficient in controlling the disease. The two different agroforestry systems (Poró alone and its combination with Cashá) had different behaviors. Indeed, in comparison with full sun exposure, the combined system, providing less canopy openness, was associated with a larger latent rust area $(P<0.0001)$ but had no effect on the rust area with uredospores $(P=0.4030)$, whereas the Poró-based system had no effect on the latent rust area $(P=0.8479)$ but negatively affected the rust area with uredospores $(P=0.0015)$. Their common point was their positive effect on parasitism by L. lecanii $(P<0.0001$ for the Poró based system and $P=0.0013$ for the combined system). Within the rust system, the presence of necrosis due to rust was positively explained by the latent rust area $(P=0.0027)$ and the presence of rust area parasitized with $L$. lecanii $(P=0.0026)$. The presence of the rust area parasitized by $L$. lecanii was also positively dependent on the area with uredospores $(P=$ $0.0001)$, the latent rust area $(P=0.0021)$, and, to a lesser extent, the inoculum stock $(P=0.0041)$. The inoculum stock was mostly negatively dependent on fungicide treatments $(P<0.0001)$ and positively on the rust area with uredospores $(P<0.0001)$. The intensity of sporulation in untreated plots was approximately $58 \times$ $10^{3}$ uredospores $\mathrm{cm}^{-2}$ (Fig. 2A) whereas, in sprayed plots, the

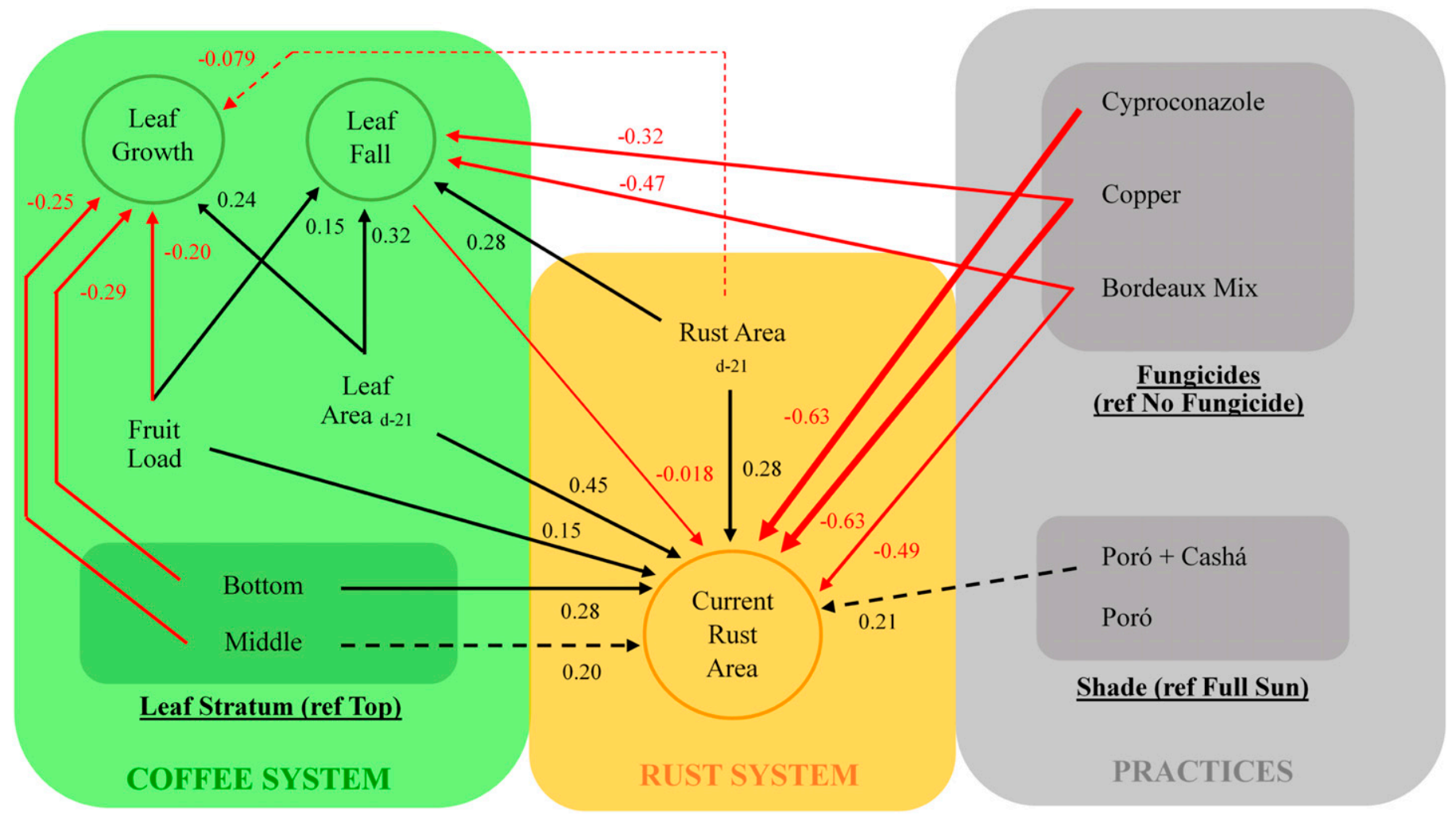

Fig. 1. Validated structural equation model of relationships between coffee phenology, rust development, and plot management for the field monitoring experiment. Darker and lighter solid arrows represent significant $(P<0.001)$ positive and negative paths, respectively. Dotted arrows represent less significant relationships $(0.001<P<0.05)$. Response variables appear in ellipsoids. Effects of the factor modalities were compared with a reference modality for each factor, indicated in parentheses. The thickness of the paths was scaled according to the magnitude of the scale-standardized estimates.

TABLE 4. Significant relationships found through laboratory experiment structural equation modeling analysis ${ }^{\mathrm{a}}$

\begin{tabular}{|c|c|c|c|c|c|}
\hline Variables & Latent area & Sporulation area & Inoculum & Lecanii & Necrosis \\
\hline Fruit load & & $\ldots$ & $0.14 * * *$ & $\ldots$ & $\ldots$ \\
\hline Bottom stratum & $0.76^{* * * *}$ & $\ldots$ & $\ldots$ & $\ldots$ & $\ldots$ \\
\hline Middle stratum & $0.49 * * *$ & $\ldots$ & $\ldots$ & $\ldots$ & $\ldots$ \\
\hline Poró + Cashá shade & $0.54 * * *$ & $\ldots$ & $\ldots$ & $0.69^{* *}$ & $\ldots$ \\
\hline Cyproconazole & $-0.57 * * *$ & $-1.76^{* * *}$ & $-1.18 * * *$ & $\ldots$ & $\ldots$ \\
\hline Copper & $-0.84 * * *$ & $-1.95 * * *$ & $-1.32 * * *$ & $\ldots$ & $\ldots$ \\
\hline Bordeaux mix & $-0.38 * * *$ & $-0.45 * *$ & $-0.30 * * *$ & $\ldots$ & $\ldots$ \\
\hline Inoculum & $\ldots$ & $\ldots$ & $\ldots$ & $0.06 * *$ & $\ldots$ \\
\hline Lecanii & $\ldots$ & $\ldots$ & $\ldots$ & $\ldots$ & $0.57 * *$ \\
\hline
\end{tabular}

${ }^{a}$ Explanatory variables are in columns and response variables in rows. Coefficients are the scale-standardized estimates in order to compare variable effects. Coefficients for factor modalities describe the effect of the modality compared with the reference modality of the factor. Asterisks: *, **, and *** indicate $P<$ $0.05,0.01$, and 0.0001 , respectively. 
intensity was only $49 \times 10^{3}$ uredospores $\mathrm{cm}^{-2}$ (Fig. 2B) for rust areas with uredospores ranging from 0 to $5 \mathrm{~cm}^{2}$ per branch in ( $95 \%$ of the recorded area).

\section{DISCUSSION}

The integrated pathway analysis developed in the SEM method allowed us to unravel rust behavior considering host dynamics and some common management patterns for Coffea arabica crops in Central America. The multiplicity of interactions between coffee plants, rust and the management patterns found with both field (Fig. 1) and laboratory data (Table 4) is another illustration of the complexity of the pathways involved in the full expression of a plant disease such as CLR.

Rust regulation by coffee phenology dynamics. To gain a better understanding of the interactions existing between rust area and coffee phenology dynamics, we proposed two subschemes, deduced from the main scheme of the field data SEM (Fig. 1), focusing on how coffee vegetative (Fig. 3) and reproductive (Fig. 4) growth affects rust development.

From the pathway analysis, we identified effects where host and pathogen developments interact (Fig. 3). Within a coffee system, foliage density was a source of future leaf growth, in accordance with the source-sink theory (Cournede et al. 2007). Leaf renewal had an immediate rust dilution effect (Calonnec et al. 2013; Ferrandino 2008) by incorporating healthy leaves into the system but foliage density also amounted to a surface available for future infection by CLR (Avelino et al. 2006; Bock 1962; Kushalappa 1981; Kushalappa et al. 1983). Future leaf removal was necessarily dependent on available leaves. In addition, the presence of rust on leaves was responsible for premature leaf fall (Kushalappa and Lagesse 1981) which, in turn, helped to regulate the expansion of this biotrophic pathogen (Kushalappa 1981).
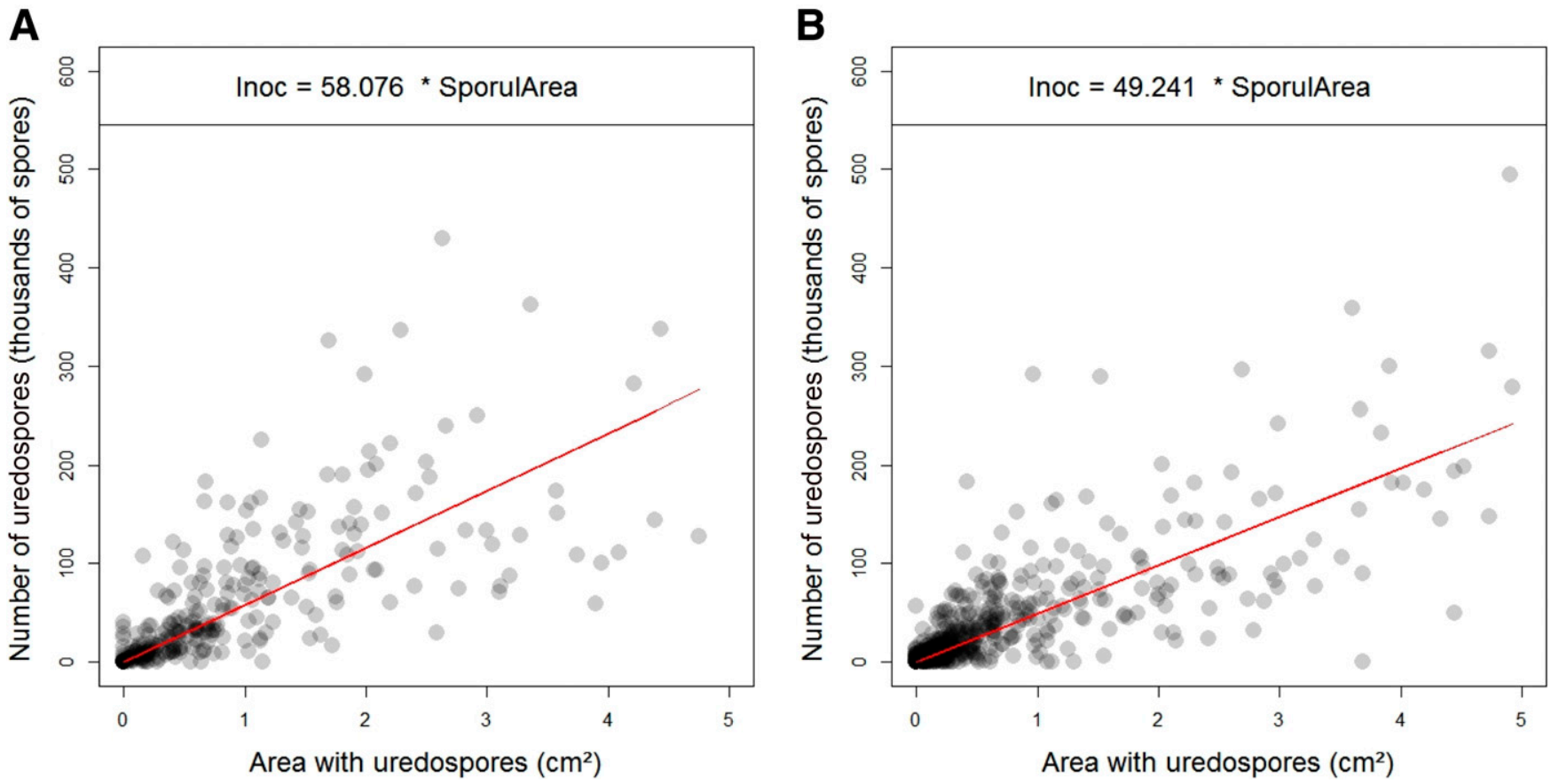

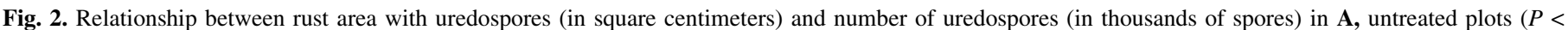

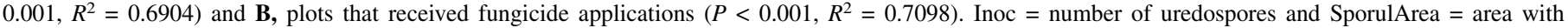
uredospores. Regressions were forced through the origin because, by definition, without visible sporulation, no uredospores were collected.

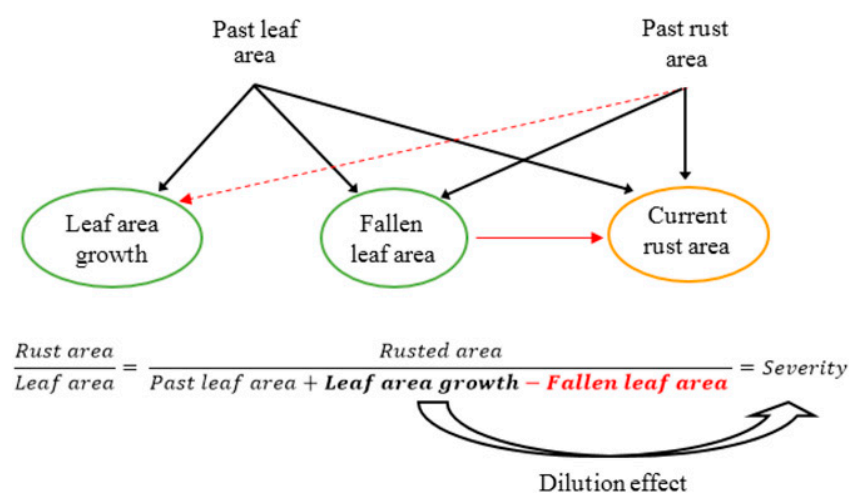

Fig. 3. Interpretation scheme for the main interactions between coffee vegetative growth and rust development and explanation of the dilution theory (Ferrandino 2008). Darker and lighter solid arrows represent significant $(P<$ $0.001)$ positive and negative paths, respectively. Dotted arrows represent less significant relationships $(0.001<P<0.05)$. Empty arrows represent hypothetical effects. The thickness of the paths was scaled according to the magnitude of the scale-standardized estimates.

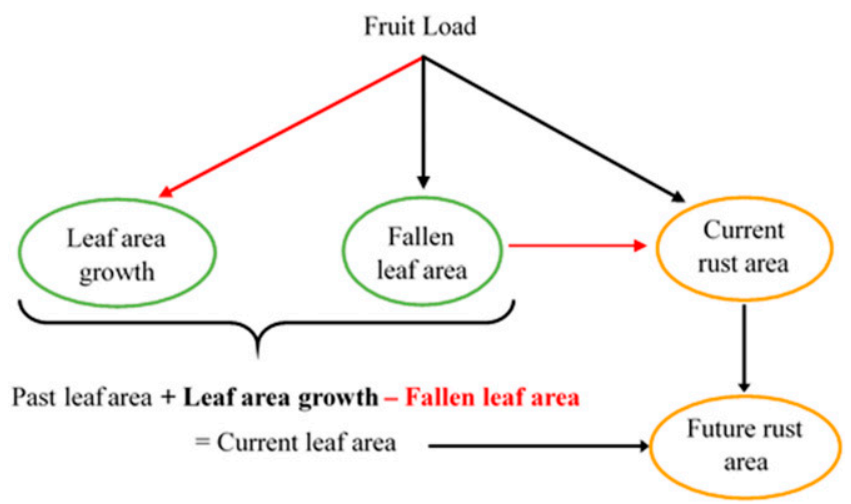

Fig. 4. Interpretation of the main interactions between coffee reproductive growth and rust development. Darker and lighter arrows represent significant $(P<0.001)$ positive and negative paths, respectively. The thickness of the paths was scaled according to the magnitude of the scale-standardized estimates. 
The reproductive growth of the coffee plants also affected rust development, as was already observed in many studies (Avelino et al. 2006; Costa et al. 2006; De Carvalho et al. 2001; López-Bravo et al. 2012). Our study showed that this global effect was mainly driven by the incorporation of fruit as a sink, competing with leaf growth and enhancing leaf fall (Fig. 4) which, in turn, affected rust development (Cannell 1985; Cournede et al. 2007). The analysis of the laboratory data suggested that fruit load affected the rust sporulation stage and had no effect on tissue colonization (Table 4). This seems contradictory to what we deduced from the field data, where fruit load increased rust area. We put forward the hypothesis that this apparent contradiction was due to the lack of temporal dimension in the laboratory data, where destructive sampling was carried out: the higher inoculum stock observed with high fruit loads will, with time, necessarily increase the number of rust infections and lead to larger rust areas, as found in the field experiment SEM analysis.

Considering this strong interdependence of disease and host plant development, Waller (1982), Ferrandino (2008), and Calonnec et al. (2013) emphasized the importance of measuring indicators that do not depend on both entities. Indeed, the incidence and the severity of a disease represent rates of diseased leaves and infested leaf area which, therefore, can vary as a function of the vegetative status of the coffee plant. Another way to fight rust might be to enhance coffee leaf renewal. Studying the effects of different nutrition strategies and pruning to increase rust dilution would be of great interest. When the objective of an experiment is to study the dynamics of an epidemic, both the host plant and disease development should be monitored to compute an apparent growth rate of the disease corrected for host growth (Kushalappa and Ludwig 1982). If the objective is to understand the effect of management practices on the disease itself, it might be of interest to observe the disease on the scale of the lesions, describing their different symptoms and signs.

To our knowledge, there are very few studies under controlled conditions showing differences in leaf physiological resistance depending on the branch or plant fruit load (Eskes and de Souza 1981). Our results tended to show that the positive relationship between fruit load and coffee rust incidence or severity was also (mainly) due to reduced growth of the coffee branch, and not only lower physiological resistance.

Effects of shade trees and coffee leaf strata on rust development stages. Shade trees and coffee leaf strata can be considered as different levels of light interception by coffee leaves. These factors cause microclimate variations that directly affect coffee phenology and rust development (López-Bravo et al. 2012).

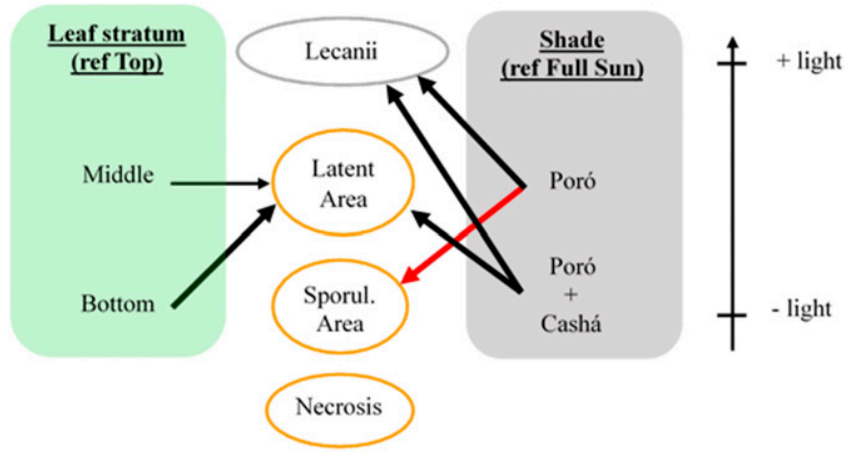

Fig. 5. Main effects of shade agroforestry systems and coffee leaf strata on rust development found through the structural equation modeling analysis on laboratory data. Darker and lighter arrows represent significant $(P<0.001)$ positive and negative paths, respectively. Sporul. Area $=$ sporulation area. Effects of the factor modalities were compared with a reference modality for each factor, indicated in parentheses. The thickness of the paths was scaled according to the magnitude of the scale-standardized estimates.
Our laboratory data revealed that both factors had multiple paths of action and opposite effects on rust development (Fig. 5), which might explain the controversial results of previous shade studies.

We highlighted antagonistic effects of shade conditions on tissue colonization and sporulation. Low radiation in low coffee strata, or in the combined agroforestry system, was associated with better development of latent rust areas (Eskes 1982), whereas the Poróbased agroforestry system limited the areas with uredospores (Toniutti et al. 2017). The negative effect of light on the latent rust area could be explained by the role of light in activating certain plant protection compounds such as reactive oxygen species (Bechtold, et al. 2005; Roberts and Paul 2006). Another hypothesis is that larger latent areas are the result of a larger number of successful infections that could be favored by the shade conditions (LópezBravo et al. 2012). As regards the middle stratum effect, the higher latent rust area might also be due to the branch fruit load. As already indicated, it is known, and shown in our study, that the fruit load increases rust intensity at plot and plant levels; however, this relationship also exists at branch level (Eskes and de Souza 1981), and the most productive branches are those of the middle stratum of the coffee plant. This effect was not found in our study, because fruit load was not disaggregated as a function of the branch stratum when counting the fruiting nodes. Radiation and nutrition might explain shade effects on areas with uredospores. Toniutti et al. (2017) hypothesized that leaves fully exposed to sunlight (full sun management, in our case) have a hotter temperature regime conducive to sporulation. However, the negative effect of the Poró-based agroforestry system on infected areas was not observed with the low coffee leaf strata or the combined agroforestry system, which had denser shade cover. Another pathway is probably involved, related to nitrogen $(\mathrm{N})$ recycling, which is known to be higher under the Poró system compared with the Poró-Cashá combined shade system ( +40 to $94 \%$, depending on pruning intensity) (Haggar et al. 2011). This higher $\mathrm{N}$ provision is less conducive to rust sporulation according to Toniutti et al. (2017). Our study also revealed that shade promoted rust parasitism by L. lecanii, as shown by Vandermeer et al. (2009). Finally, the fact that the area with uredospores was similar under dense shade to that with full sun exposure could only be explained by the presence of larger latent rust areas under the shade conditions.

In terms of a rust control strategy, the Poró-based agroforestry system seemed to be better than the combined agroforestry system. Indeed, compared with a system with full sun exposure, the

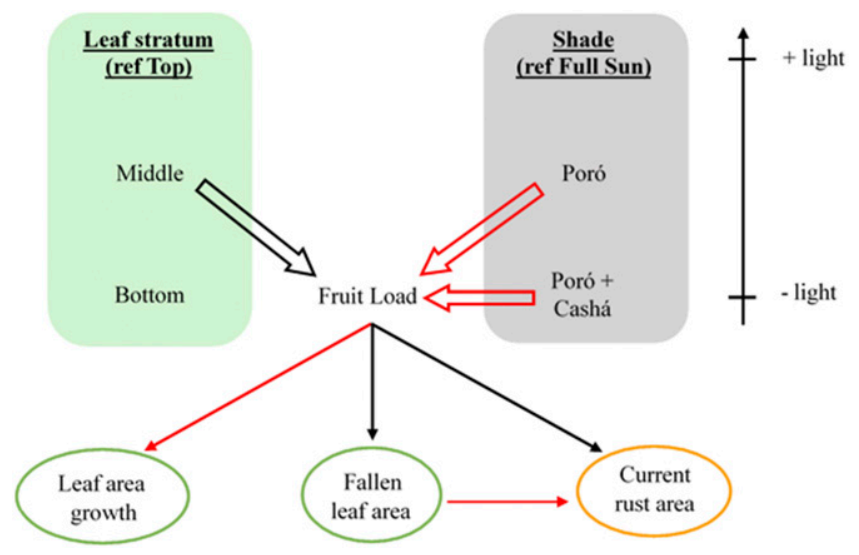

Fig. 6. Hypothetical effects of shade agroforestry systems and coffee leaf strata on fruit load and observed effects of fruit load on coffee phenology and rust development found through the structural equation modeling (SEM) analysis on field data. Darker and lighter arrows represent significant $(P<$ $0.001)$ positive and negative paths, respectively. Empty arrows represent hypothetical effects. Effects of the factor modalities were compared with a reference modality for each factor, indicated in parentheses. The thickness of the SEM paths was scaled according to the magnitude of the scale-standardized estimates. 
Poró-based agroforestry system limited rust sporulation and did not increase latent rust areas, whereas the combined agroforestry system was responsible for larger latent rust areas and did not affect rust areas with uredospores. In addition, the natural enemy of rust, L. lecanii, was also more abundant under the Poró-based shade than under the combined shade.

Shade trees and coffee leaf stratum effects on coffee phenology. In comparison with full sun exposure, no effect of either agroforestry systems was observed on coffee leaf phenology (Fig. 1), in contradiction to previous results reporting that a higher level of shading is unfavorable for leaf growth (Campanha et al. 2004; Jaramillo-Botero et al. 2010; López-Bravo et al. 2012). However, we found a negative effect on leaf growth for lower coffee leaf strata in comparison with upper strata. This result might be explained by the lower interception of light, which reduces photosynthesis under such conditions (Charbonnier et al. 2013), and leaf area growth considering the source-sink theory (Cannell 1985; Cournede et al. 2007). Although some studies found a positive effect of low leaf strata and shade trees on leaf retention (Avelino et al. 1991; Campanha et al. 2004; López-Bravo et al. 2012; Staver et al. 2001), our analysis showed no direct effect. However, it is known that coffee yields are lower under shade because of light interception, which reduces flower initiation (DaMatta and Rena 2002). In our study, we did not create a submodel explaining fruit load, because of the poor measurement accuracy of fruit load and differences in terms of time steps that were difficult to integrate in the SEM analysis. However, we found that the plant fruit load was significantly lower $(P=0.018)$ under the Poró-based system (mean fruit load $=384$ ) and the combined system (mean fruit load $=205$ ) in comparison with full sun exposure (mean fruit load $=452$ ). In our analysis, the shade effect on leaf retention was probably integrated into the fruit load effect (Fig. 6). Finally, the absence of direct branch stratum effects on leaf retention suggested that this effect was possibly negligible. Differences in leaf retention are expected due to rust intensity, which is greater on lower branches.

Relationships between different rust life cycle stages and rust parasitism by $L$. lecanii. Over the same time step, we found mostly logical relationships between the different rust life cycle stages. Indeed, for larger latent rust areas, larger areas with uredospores and with necrosis due to rust were observed (Fig. 7). Moreover, the inoculum stock was mainly explained by the fungicide treatment, the area with uredospores, and the fruit load (Table 4). This result shows that fungicide applications directly act upon sporulation intensity, in addition to indirectly acting by limiting the area with uredospores. Considering now the relationships between the rust system and a natural enemy, L. lecanii, over the same time step, we logically found more L. lecanii where rust was more abundant (Fig. 7). Given L. lecanii hyperparasitism, the rust lesions developed necrosis. Our results also shed some additional light on the findings published on L. lecanii influence on rust (Jackson et al. 2012; Vandermeer et al. 2009). The statistical

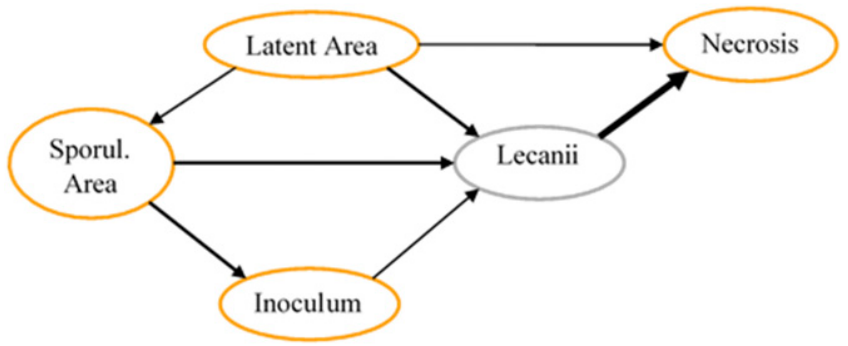

Fig. 7. Main relationships between different rust life cycle stages and rust parasitism by Lecanicillium lecanii found through the structural equation modeling analysis on laboratory data. Arrows represent significant $(P<0.001)$ paths; Sporul. Area $=$ sporulation area. The thickness of the paths was scaled according to the magnitude of the scale-standardized estimates. 1-year time lag relationship between outbreaks of L. lecanii and low rust intensities reported by Jackson et al. (2012), suggesting delayed natural rust regulation, might be explained alternatively by four effects: (i) the well-known biennial coffee yield behavior (DaMatta 2004), (ii) the positive relationship between fruit load and rust intensity, which (iii) exacerbates biennality because of yield losses due to rust (Cerda et al. 2017), and (iv) increases L. lecanii parasitism.

Effect of fungicide type on coffee phenology, rust development, and rust parasitism by $L$. lecanii. All of the fungicides applied in our study were able to control rust at all of its stages except the necrosis of lesions. This is surprising, given their main properties. Copper-based fungicides, including Bordeaux mixture, mainly protect (da Cunha et al. 2004) the plant from new infections and, therefore, should mainly reduce the latent rust area, whereas systemic fungicides mainly prevent postinfectious processes such as colonization and sporulation (Chalfoun and Carvalho 1999; Santos et al. 2002). Our results provide evidence of additional effects of copper-based fungicides on sporulation and of systemic fungicides on preventing infections. However, these fungicides had different efficiency levels (Table 4). For any rust development stage, the commercial copper-based fungicide was found to be more effective than cyproconazole, itself more effective than Bordeaux mixture (Fig. 8). In 1974, Mulinge and Griffiths also observed a higher efficacy of a commercial copper-based fungicide than a systemic one against rust but did not provide any hypothesis (Mulinge and Griffiths 1974). Our result may have been related to differences in doses, application times, or rust levels when fungicides were applied. $H$. vastatrix resistance to cyproconazole cannot be excluded, even if there is still no evidence of such a possibility (Rozo-Peña and Cristancho-Ardila 2010). For instance, Bordeaux mixture was associated with organic management, where rust levels were higher, which surely contributed to reducing its effects (Zambolim 2016). Furthermore, our study highlighted additional, direct fungicide effects on the coffee plants. The tonic effect on coffee plant foliage resulting from copper-based fungicide sprays was mentioned in previous studies (Bock 1962; Brinate et al. 2015; Cannell 1985; da Cunha et al. 2004; Mulinge and Griffiths 1974; Van der Vossen and Browning 1978). The surprising absence of fungicide effects on rust parasitism by the fungus $L$. lecanii might be explained by the late emergence of this parasite during and after harvesting periods, when fungicides were no longer applied.

Methodological features. Many methodological choices were important in our study to achieve the goals we set. First, SEM analysis allowed us to reveal multiple pathways existing between several submodels. We then selected variables that did

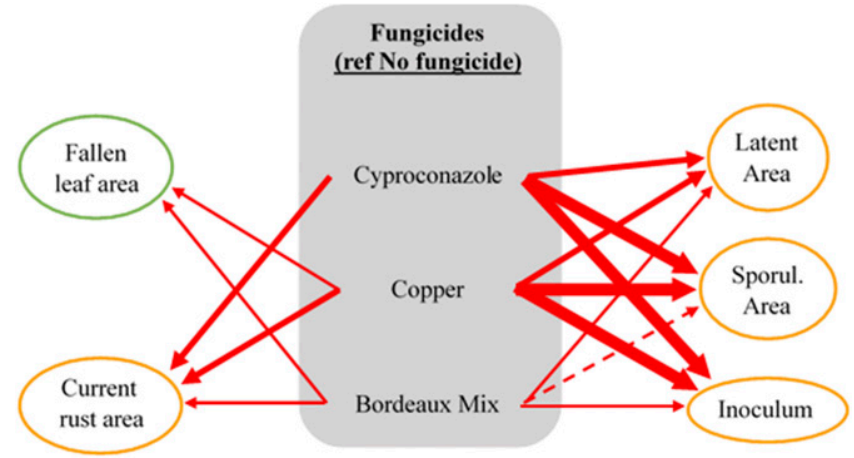

Fig. 8. Main relationships between different types of fungicides, coffee phenology, and rust found through the structural equation modeling analysis on field data (on the left) and laboratory data (on the right). Solid arrows represent significant $(P<0.001)$ paths; Sporul. Area $=$ sporulation area. Dotted arrows represent less significant relationships $(0.001<P<0.05)$. Effects of the factor modalities were compared with a reference modality, indicated in parentheses. The thickness of the paths was scaled according to the magnitude of the scalestandardized estimates. 
not depend at the same time on coffee and rust systems, which led us to exclude incidence and severity indicators (Waller 1982). We decided to consider time in this analysis, in order to highlight delayed effects. By considering different rust stages in the analysis, we were able to show antagonistic effects of shading and of the coffee leaf stratum depending on the stage, which are impossible to distinguish otherwise. This approach also led us to elaborate a way of estimating the inoculum stock in unsprayed plots, based on image analysis (Fig. 2), which is less timeconsuming than counting methods.

\section{ACKNOWLEDGMENTS}

We thank CATIE for allowing access to their long-term trial on coffeebased agroforestry systems and P. Biggins for reviewing the English.

\section{LITERATURE CITED}

Allinne, C., Savary, S., and Avelino, J. 2016. Delicate balance between pest and disease injuries, yield performance, and other ecosystem services in the complex coffee-based systems of Costa Rica. Agric. Ecosyst. Environ. 222: $1-12$

Avelino, J., Allinne, C., Cerda, R., Willocquet, L., and Savary, S. 2018. Multiple-disease system in coffee: From crop loss assessment to sustainable management. Annu. Rev. Phytopathol. 56:611-635.

Avelino, J., Muller, R. A., Cilas, C., and Velasco, H. 1991. Développement et comportement de la rouille orangée du caféier (Hemileia vastatrix Berk. et Br.) dans des plantations en cours de modernisation plantées de variétés naines dans le Sud-Est du Mexique. Cafe, Cacao, The (Paris) 35:21-42.

Avelino, J., Ten Hoopen, G. M., and DeClerck, F. A. J. 2011. Ecological mechanisms for pest and disease control in coffee and cacao agroecosystems of the Neotropics. Pages 91-117 in: Ecosystem Services from Agriculture and Agroforestry Measurement and Payment. B. Rapidel, F. A. J. DeClerck, J.-F. Le Coq, and J. Beer, eds. Earthscan Publications, London, U.K.

Avelino, J., Willocquet, L., and Savary, S. 2004. Effects of crop management patterns on coffee rust epidemics. Plant Pathol. 53:541-547.

Avelino, J., Zelaya, H., Merlo, A., Pineda, A., Ordoñez, M., and Savary, S. 2006. The intensity of a coffee rust epidemic is dependent on production situations. Ecol. Modell. 197:431-447.

Bechtold, U., Karpinski, S., and Mullineaux, P. M. 2005. The influence of the light environment and photosynthesis on oxidative signalling responses in plant-biotrophic pathogen interactions. Plant Cell Environ. 28:1046-1055.

Bock, K. R. 1962. Seasonal periodicity of coffee leaf rust and factors affecting the severity of outbreaks in Kenya Colony. Trans. Br. Mycol. Soc. 45: 289-300.

Bolker, B. M., Brooks, M. E., Clark, C. J., Geange, S. W., Poulsen, J. R., Stevens, M. H. H., and White, J. S. S. 2009. Generalized linear mixed models: A practical guide for ecology and evolution. Trends Ecol. Evol. 24: 127-135.

Bote, A. D., and Jan, V. 2016. Branch growth dynamics, photosynthesis, yield and bean size distribution in response to fruit load manipulation in coffee trees. Trees 30:1275-1285.

Boudrot, A., Pico, J., Merle, I., Granados, E., Vílchez, S., Tixier, P., Virginio-Filho, E. de M., Casanoves, F., Tapia, A., Allinne, C., Rice, R. A., and Avelino, J. 2016. Shade effects on the dispersal of airborne Hemileia vastatrix uredospores. Phytopathology 106:572-580.

Brinate, S. V. B., Martins, L. D., Pereira, G. N. G., Cunha, V. V., Sotero, A. de J., Amaral, J. F. T., Junior, W. C. J., and Tomaz, M. A. 2015. Copper can influences growth, disease control and production in arabica coffee trees. Aust. J. Crop Sci. 9:678-683.

Brown, J. S., Kenny, M. K., Whan, J. H., and Merriman, P. R. 1995. The effect of temperature on the development of epidemics of coffee leaf rust in Papua New Guinea. Crop Prot. 14:671-676.

Calonnec, A., Burie, J.-B., Langlais, M., Guyader, S., Saint-Jean, S., Sache, I., and Tivoli, B. 2013. Impacts of plant growth and architecture on pathogen processes and their consequences for epidemic behaviour. Eur. J. Plant Pathol. 135:479-497.

Campanha, M. M., Santos, R. H. S., de Freitas, G. B., Martinez, H. E. P., Garcia, S. L. R., and Finger, F. L. 2004. Growth and yield of coffee plants in agroforestry and monoculture systems in Minas Gerais, Brazil. Agrofor. Syst. 63:75-82.

Cannell, M. G. R. 1985. Physiology of coffee crop. Pages 108-134 in: Coffee, Botany, Biochemistry and Production of Beans and Beverage. M. N. Clifford and K. C. Willson, eds. Croom Helm, London, U.K.
Capucho, A. S., Zambolim, L., Lopes, U. N., and Milagres, N. S. 2013. Chemical control of coffee leaf rust in Coffea canephora cv. conilon. Australas. Plant Pathol. 42:667-673.

Castellanos, L., Nicao, M. E. L., Muiño, B. L., Pérez, R. H., Guillén-Sánchez, D., and Lopez-Martínez, V. 2012. Effect of six fungicides on Lecanicillium (Verticillium) lecanii (Zimm.) Zare \& Gams. J. Food Agric. Environ. 10:1142-1145.

Cerda, R., Avelino, J., Gary, C., Tixier, P., Lechevallier, E., and Allinne, C. 2017. Primary and secondary yield losses caused by pests and diseases: Assessment and modeling in coffee. PLoS One 12:e0169133.

Chalfoun, S. M., and Carvalho, V. L. 1999. Controle químico da ferrugem (Hemileia vastatrix Berk \& Br.) do cafeeiro através de diferentes esquemas de aplicação. Pesqui. Agropecu. Bras. 34:363-367.

Charbonnier, F., le Maire, G., Dreyer, E., Casanoves, F., Christina, M., Dauzat, J., Eitel, J. U. H., Vaast, P., Vierling, L. A., and Roupsard, O. 2013. Competition for light in heterogeneous canopies: Application of MAESTRA to a coffee (Coffea arabica L.) agroforestry system. Agric. For. Meteorol. 181: 152-169.

Costa, M. J., Zambolim, L., and Rodrigues, F. A. 2006. Efeito de níveis de desbaste de frutos do cafeeiro na incidência da ferrugem, no teor de nutrientes, carboidratos e açúcares redutores. Fitopatol. Bras. 31:564-571.

Cournede, P.-H., Mathieu, A., Houllier, F., Barthelemy, D., and de Reffye, P. 2007. Computing competition for light in the GREENLAB model of plant growth: A contribution to the study of the effects of density on resource acquisition and architectural development. Ann. Bot. 101: 1207-1219.

Coutinho, T. A., Van Asch, M. A. J., and Rijkenberg, F. H. J. 1995. The effects of the fungicide Bayfidan on infection structure formation by Hemileia vastatrix in Coffea arabica cv. Caturra. Mycol. Res. 99:793-798.

da Cunha, R. L., Mendes, A. N. G., and Chalfoun, S. M. 2004. Controle químico da ferrugem do cafeeiro (Coffea arabica L.) e seus efeitos na produção e preservação do enfolhamento. Cienc. Agrotec. 28:990-996.

DaMatta, F. M. 2004. Ecophysiological constraints on the production of shaded and unshaded coffee: A review. Field Crops Res. 86:99-114.

DaMatta, F. M., and Rena, A. B. 2002. Ecofisiologia de cafezais sombreados e a pleno Sol. Pages 93-136 in: O Estado da Arte de Tecnologias na Produção de Café. L. Zambolim, ed. Universidade Federal de Viçosa, Viçosa, MG, Brazil.

De Carvalho, V. L., Chalfoun, S. M., Castro, H. A., and Carvalho, V. D. 2001. Influência de diferentes níveis de produção sobre a evolução da ferrugem do cafeeiro e sobre teores foliares de compostos fenólicos. Cienc. Agrotec. 25: 49-54.

De Carvalho, V. L., da Cunha, R. L., and Silva, N. R. N. 2012. Alternativas de controle de doenças do cafeeiro. Coffee Sci. 7:42-49.

de Souza, A. F., Zambolim, L., de Jesus Júnior, V. C., and Cecon, P. R. 2011. Chemical approaches to manage coffee leaf rust in drip irrigated trees. Australas. Plant Pathol. 40:293-300.

Eskes, A. B. 1982. The effect of light intensity on incomplete resistance of coffee to Hemileia vastatrix. Neth. J. Plant Pathol. 88:191-202.

Eskes, A. B., and de Souza, E. Z. 1981. Ataque da ferrugem em ramos com e sem produçao, de plantas do cultivar catuaí. Pages 186-188 in: Congresso Brasileiro de Pesquisas Cafeeiras, Sao Lourenzo, Minas Gerais, Brazil.

Ferrandino, F. J. 2008. Effect of crop growth and canopy filtration on the dynamics of plant disease epidemics spread by aerially dispersed spores. Phytopathology 98:492-503.

Grace, J. B. 2006. Structural Equation Modeling and Natural Systems. Cambridge University Press, Cambridge, UK.

Haggar, J., Barrios, M., Bolaños, M., Merlo, M., Moraga, P., Munguia, R., Ponce, A., Romero, S., Soto, G., Staver, C., and Virginio, E. de M. F. 2011. Coffee agroecosystem performance under full sun, shade, conventional and organic management regimes in Central America. Agrofor. Syst. 82: 285-301.

Hindorf, H., and Omondi, C. O. 2011. A review of three major fungal diseases of Coffea arabica L. in the rainforests of Ethiopia and progress in breeding for resistance in Kenya. J. Adv. Res. 2:109-120.

Jackson, D., Skillman, J., and Vandermeer, J. 2012. Indirect biological control of the coffee leaf rust, Hemileia vastatrix, by the entomogenous fungus Lecanicillium lecanii in a complex coffee agroecosystem. Biol. Control 61: 89-97.

Jaramillo-Botero, C., Santos, R. H. S., Martinez, H. E. P., Cecon, P. R., and Fardin, M. P. 2010. Production and vegetative growth of coffee trees under fertilization and shade levels. Sci. Agric. 67:639-645.

Jha, S., Bacon, C. M., Philpott, S. M., Ernesto Méndez, V., Läderach, P., and Rice, R. A. 2014. Shade coffee: Update on a disappearing refuge for biodiversity. Bioscience 64:416-428.

Kushalappa, A. C. 1981. Linear models applied to variation in the rate of coffee rust development. J. Phytopathol. 101:22-30.

Kushalappa, A. C., Akutsu, M., and Ludwig, A. 1983. Application of survival ratio for monocyclic process of Hemileia vastatrix in predicting coffee rust infection rates. Phytopathology 73:96-103. 
Kushalappa, A. C., and Lagesse, R. M. 1981. LEAFAL: A computer program for quantitative analysis of leaf fall in coffee principally from rust. J. Phytopathol. 101:97-105.

Kushalappa, A. C., and Ludwig, A. 1982. Calculation of apparent infection rate in plant diseases: Development of a method to correct for host growth. Phytopathology 72:1373-1377.

Lasco, R. D., Delfino, R. J. P., and Espaldon, M. L. O. 2014. Agroforestry systems: Helping smallholders adapt to climate risks while mitigating climate change. Wiley Interdiscip. Rev. Clim. Change 5:825-833.

Lefcheck, J. S. 2016. PIECEWISESEM : Piecewise structural equation modelling in R for ecology, evolution, and systematics. Methods Ecol. Evol. 7:573-579.

López-Bravo, D. F., Virginio-Filho, E. de M., and Avelino, J. 2012. Shade is conducive to coffee rust as compared to full sun exposure under standardized fruit load conditions. Crop Prot. 38:21-29.

Martins, S. J., Soares, A. C., Medeiros, F. H. V., Santos, D. B. C., and Pozza, E. A. 2015. Contribution of host and environmental factors to the hyperparasitism of coffee rust under field conditions. Australas. Plant Pathol. 44: 605-610.

McCook, S., and Vandermeer, J. 2015. The big rust and the red queen: Longterm perspectives on coffee rust research. Phytopathology 105:1164-1173.

Mulinge, S. K., and Griffiths, E. 1974. Effects of fungicides on leaf rust, berry disease, foliation and yield of coffee. Trans. Br. Mycol. Soc. 62:495-507.

Perfecto, I., Rice, R. A., Greenberg, R., and Van der Voort, M. E. 1996. Shade coffee: A disappearing refuge for biodiversity. Bioscience 46:598-608.

Poeydebat, C., Carval, D., Tixier, P., Daribo, M. O., and de Lapeyre de Bellaire, L. 2018. Ecological regulation of black leaf streak disease driven by plant richness in banana agroecosystems. Phytopathology 108:1184-1195.

R Development Core Team. 2018. R: A Language and Environment for Statistical Computing. R Foundation for Statistical Computing, Vienna, Austria.

Rayner, R. W. 1962. The control of coffee rust in Kenya by fungicides. Ann. Appl. Biol. 50:245-261.

Roberts, M. R., and Paul, N. D. 2006. Seduced by the dark side: Integrating molecular and ecological perspectives on the influence of light on plant defence against pests and pathogens. New Phytol. 170:677-699.

Rozo-Peña, Y. I., and Cristancho-Ardila, M. A. 2010. Evaluación de la susceptibilidad de Hemileia vastatrix berk. \& Br., a fungicidas del grupo de los triazoles. Cenicafé 61:297-314.

Salgado, B. G., Macedo, R. L. G., de Carvalho, V. L., Salgado, M., and Venturin, N. 2007. Progresso da ferrugem e da cercosporiose do cafeeiro consorciado com grevílea, com ingazeiro e a pleno sol em Lavras - MG. Cienc. Agrotec. 31:1067-1074.

Santos, J. M. F., Oliveira, S. H. F., Domingues, R. J., and Guzzo, S. D. 2002. Avaliação da eficácia de Fungicidas sistêmicos no controle da ferrugem
(Hemileia vastatrix) do cafeeiro, sob chuva simulada. Arq. Inst. Biol. (Sao Paulo) 69:45-49.

Shipley, B. 2009. Confirmatory path analysis in a generalized multilevel context. Ecology 90:363-368.

Soto-Pinto, L., Perfecto, I., and Caballero-Nieto, J. 2002. Shade over coffee: Its effects on berry borer, leaf rust and spontaneous herbs in Chiapas, Mexico. Agrofor. Syst. 55:37-45.

Staver, C., Guharay, F., Monterroso, D., and Muschler, R. G. 2001. Designing pest-suppressive multistrata perennial crop systems: Shade-grown coffee in Central America. Agrofor. Syst. 53:151-170.

Talhinhas, P., Batista, D., Diniz, I., Vieira, A., Silva, D. N., Loureiro, A., Tavares, S., Pereira, A. P., Azinheira, H. G., Guerra-Guimarães, L., Várzea, V., and Do Céu Silva, M. 2017. The coffee leaf rust pathogen Hemileia vastatrix: One and a half centuries around the tropics. Mol. Plant Pathol. 18: 1039-1051.

Toniutti, L., Breitler, J.-C., Etienne, H., Campa, C., Doulbeau, S., Urban, L., Lambot, C., Pinilla, J.-C. H., and Bertrand, B. 2017. Influence of environmental conditions and genetic background of Arabica coffee (C. arabica $\mathrm{L}$ ) on leaf rust (Hemileia vastatrix) pathogenesis. Front. Plant Sci. 8:2025.

Vaast, P., Angrand, J., Franck, N., Dauzat, J., and Genard, M. 2005. Fruit load and branch ring-barking affect carbon allocation and photosynthesis of leaf and fruit of Coffea arabica in the field. Tree Physiol. 25:753-760.

Vandermeer, J., Perfecto, I., and Liere, H. 2009. Evidence for hyperparasitism of coffee rust (Hemileia vastatrix) by the entomogenous fungus, Lecanicillium lecanii, through a complex ecological web. Plant Pathol. 58: 636-641.

Van der Vossen, H. A. M., and Browning, G. 1978. Prospects of selecting genotypes of Coffea arabica L. which do not require tonic sprays of fungicide for increased leaf retention and yield. J. Hortic. Sci. 53:225-233.

Villegas-García, C., and Baeza-Aragón, C. A. 1990. Diseminación de Hemileia vastatrix Berk. y Br. a nivel del árbol, en un foco natural. Cenicafé 41: 39-49.

Waller, J. M. 1982. Coffee rust-epidemiology and control. Crop Prot. 1: 385-404.

Wilcox, C. D., Brent, S., Dove, W., McDavid, D., and Greer, D. B. 2002. Image Tool Version 3.0. UTHSCSA, San Antonio, TX.

Zadoks, J. C., and Schein, R. D. 1979. Epidemiology and Plant Disease Management. Oxford University Press, New York.

Zambolim, L. 2016. Current status and management of coffee leaf rust in Brazil. Trop. Plant Pathol. 41:1-8.

Zuur, A. F., Ieno, E. N., Walker, N. J., Saveliev, A. A., and Smith, G. M. 2009. Mixed Effects Models and Extensions in Ecology with R. Statistics for Biology and Health, Vol. XXII. Springer, New York. 